ISSN 0258-7122

Bangladesh J. Agril. Res. 33(3) : 439-448, September 2008

\title{
YIELD AND N USE EFFICIENCY OF WHEAT AS INFLUENCED BY BED PLANTING AND N APPLICATION
}

\author{
M. A. Khaleque ${ }^{1}$, N. K. PAUL ${ }^{2}$ AND CRAig A. MEISNER ${ }^{3}$
}

\begin{abstract}
Wheat (Triticum aestivum L.) was planted as winter crop using raised bed and conventional planting system with four $\mathrm{N}$ levels at Regional Wheat Research Station, Rajshahi (latitude 28 $8^{\circ} 5^{\prime} \mathrm{N}$ and longitude $92^{\circ} 58^{\prime} \mathrm{E}$ ), during November to March in 2002 and 2003 to study N content in grain and straw, uptake of total nitrogen, $\mathrm{N}$ use efficiency, fertilizer recovery percentage and grain yield. The highest $\mathrm{N}$ content in grain and straw were obtained from bed planting system with Shatabdi at $150 \% \mathrm{~N}$ treatment. Maximum total $\mathrm{N}$ uptake by the plants was found in bed elevation as compared to conventional planting system. The highest $\mathrm{N}$ use efficiency was observed at $\mathrm{N}$ zero treatment as compared to applied N levels. Shatabdi noticed highest $\mathrm{N}$ use efficiency among the crop varieties. The maximum fertilizer recovery percentage was noted in Shatabdi under bed planting system. The highest grain yield $(2,555 \mathrm{~kg} / \mathrm{ha})$ was produced from bed planting system. Significantly the highest grain yield $(2,929 \mathrm{~kg} / \mathrm{ha})$ was found in Shatabdi. The highest grain yield (3,746 kg/ha) was found when $150 \% \mathrm{~N}$ was applied. In bed planting system, the highest grain yield (3,323 $\mathrm{kg} / \mathrm{ha}$ ) was produced when $150 \% \mathrm{~N}$ was applied. The lowest grain yield $(1,177$ $\mathrm{kg} / \mathrm{ha}$ ) was obtained in zero $\mathrm{N}$ treatment. Among the varieties, Shatabdi was the best performer in bed planting system due to maximum nitrogen and protein content in grain and straw, maximum $\mathrm{N}$ use efficiency and fertilizer recovery percentage.
\end{abstract}

Key Words: Bed planting, $\mathrm{N}$ content, $\mathrm{N}$ use efficiency and fertilizer recovery percentage.

\section{Introduction}

Wheat (Triticum aestivum L.) is the first ranking cereal crop globally and it is grown from temperate irrigated to dry and high rainfall environments. It can be cultivated in areas where the winter is cool and the summer is comparatively hot. The optimum temperature for the growth of this crop is $10-20^{\circ} \mathrm{C}$ (Fischer, 1981). Sayre (1998) noted that the average wheat yield was higher in bed planting system than conventional planting tillage. Use of those practices has increased dramatically in the last decade in high yielding irrigated wheat growing areas in Mexico (Meisner et al., 1992). The use of permanent raised bed system is an

\footnotetext{
1 Senior Scientific Officer (Wheat Agronomy), RARS, BARI, Jamalpur, Bangladesh, ${ }^{2}$ Professor, Department of Botany, Rajshahi University, Rajshahi, Bangladesh, ${ }^{3}$ Adjunct Professor, Cornell University, USA.
} 
alternative practice in wheat that allows for timing of nitrogen fertilizer application to increase $\mathrm{N}$ use efficiency and to lower production cost. CIMMYT's scientists are strongly convinced that bed-planting (with or without tillage) offers a very sound method for planting wheat and other crops under high rainfall conditions where excessive moisture can cause water logging (Sayre, 1998). Bed sowing could be a good alternative for Bangladesh where wet culture is more dominant and this experiment was aimed to investigate the interaction among wheat varieties and method of sowing (tillage option) among varying nitrogen fertilizer applications.

\section{Materials and Method}

The trial was carried out at the Regional Wheat Research Center (WRC), Rajshahi to find out the suitable variety(s) for bed planting system, nitrogen use efficiency and fertilizer recovery percentage. The experimental field was a medium high land with loam to silty loam textured soil having a $\mathrm{p}^{\mathrm{H}}$ value 7.56. The initial soill $\mathrm{N}$ percent and bulk density of the experimental field were $0.084 \%$ and $1.40 \mathrm{~g} / \mathrm{cm}^{3}$, respectively. The design was strip split plot having three replications. Varieties used were Shatabdi, Gourab, Protiva and the check variety Kanchan. There were 3 factors having 32 treatments. Methods of sowing, a) conventional i.e., flat bed and b) raised bed, $15 \mathrm{~cm}$ above from the soil surface, which was made by taking the soil from the furrows maintaining $25 \mathrm{~cm}$ spacing between row to row and $75 \mathrm{~cm}$ spacing from furrow to furrow, that was placed in the main plot. Nitrogen doses viz., $0,50 \%, 100 \%, 150 \%$ of the recommended $\mathrm{N}$ (100 kg N/ha), which were placed in sub-sub plots. Two-thirds of $\mathrm{N}$ was applied as basal mixing well with soil in conventional one and in bed planting, along with furrows. The remaining one-third $\mathrm{N}$ was applied as broadcast in between the rows at crown root initiation (CR1) stage of the crop. The unit plot size was $3 \mathrm{~m} \times$ 4m. A blanket dose of PKS @ 60-40-45 kg/ha was applied in the form of Triple Super Phosphate, Muriate of Potash and Gymsum (FRG, BARC, 2005). Nitrogen was applied as urea. The seeds were sown on 3 December 2002-2003. Three samples of $1 \mathrm{~m}^{2}$ of each plot were harvested for collecting data on yield by using method as described by Bell and Fisher (1994). The grain and straw were weighed separately for each treatment after proper sun drying. Five plants were randomly collected from each treatment for recording data on yield contributing characters (Bell and Fisher, 1994).

\section{Determination of $\mathrm{N} \%$ in grain and straw}

Grain and straw samples were collected from each plot. Approximately $10 \mathrm{~g}$ of samples of each plot were preserved separately in polythene bags for chemical 
analysis to determine grain and straw nitrogen. Nitrogen content in wheat grain and straw was determined by the standard micro Kjeldahl method (Total nitrogen estimation method, AOAC, 1980). Total nitrogen uptake was estimated by multiplying oven dry weight of the sample with $\mathrm{N}$ content in respective sample. Nitrogen use efficiency (Physiological) was calculated as the ratio of grain yield to the total $\mathrm{N}$ uptake by the plants. Fertilizer recovery percentage was calculated as the ratio of $\mathrm{N}$ use efficiency to the $\mathrm{N}$ applied of each treatment multiplied by 100. All the data including yield and yield components were statistically analyzed following computer package MSTAT-C. The means were separated by using DMRT (Gomez and Gomez, 1984) at 5\% level of significance.

\section{Results and Discussion}

\section{Nitrogen content (\%) in grain and straw}

Highest nitrogen content in grain (2.13\%) and straw (0.33\%) was found in bed planting system as compared to the conventional planting system due to more uptakes of nitrate nitrogen and accumulation of carbon dioxide and solar radiation in bed planting system (Table 1). Among the varieties, the maximum nitrogen content in grain (2.18\%) and straw (0.35\%) was observed in Shatabdi followed by Gourab, Protiva, and Kanchan (Table 1). Interaction of crop varieties and bed elevation has led to highest $\mathrm{N}$ content in Shatabdi variety $(2.23 \%$ in grain and $0.40 \%$ in straw) grown under raised bed condition (Table 2). The results are in agreement with the findings of Ciobanu et al. (1995), Kumar et al. (1995) and Alom et al. (2004). Interaction of sowing method and nitrogen level had also significant effect on nitrogen content in grain and straw (Table 3 ). The highest nitrogen content in grain (2.25\%) and straw (0.48\%) was found under raised bed at $150 \% \mathrm{~N}$ application followed by $100 \% \mathrm{~N}$ and $50 \% \mathrm{~N}$ application. The lowest nitrogen content in grain (1.88\%) and straw $(0.21 \%)$ was found under conventional bed with no application of $\mathrm{N}$ (Table 3).

\section{Total nitrogen uptake}

The highest nitrogen uptake by the plants was in bed planting (40.99 kg/ha system as compared to the conventional planting system may be due to higher uptake of nitrogen (Table 1). Among the crop varieties, the maximum uptake of $\mathrm{N}$ was obtained in Shatabdi (41.26 kg/ha) followed by Kanchan, Protiva, and Gourab (Table 1). At 150\% N applicable maximum total uptake of nitrogen was noticed (100.7 kg/ha). Interaction of crop vatieties and bed elevation has led to the highest uptake of $\mathrm{N}$ in Shatabdi (79.62 kg/ha) as compared to consentient planting system (Table 1). Combined effect between sowing method and $\mathrm{N}$ 
doses, $150 \% \mathrm{~N}$ application noticed highest total uptake of $\mathrm{N}$ by the plants (106.04 kg/ha in bed elevation as compared to conventional planting.

Table 1. Effect of sowing method, variety and $\mathbf{N}$ level on $\mathbf{N}$ content, $\mathbf{N}$ use efficiency and fertilizer recovery percentage (Pooled over two years).

\begin{tabular}{l|l|l|l|l|l}
\hline Sowing method & $\begin{array}{c}\text { Nitrogen } \\
\text { content of } \\
\text { straw (\%) }\end{array}$ & $\begin{array}{c}\text { Nitrogen content } \\
\text { of grain (\%) }\end{array}$ & $\begin{array}{c}\text { Total } \\
\text { N uptake } \\
\text { (kg/ha) }\end{array}$ & $\begin{array}{c}\text { N use efficiency } \\
\text { (kg grain/ha per } \\
\text { kg uptake of N) }\end{array}$ & $\begin{array}{r}\text { Fertilizer } \\
\text { recovery } \\
\text { percentage }\end{array}$ \\
\hline $\begin{array}{l}\text { Bed planting } \\
\text { Conventional }\end{array}$ & $0.33 \mathrm{a}$ & $2.13 \mathrm{a}$ & $71.06 \mathrm{a}$ & $40.99 \mathrm{a}$ & $69.89 \mathrm{a}$ \\
planting & & $2.03 \mathrm{~b}$ & $63.28 \mathrm{~b}$ & $38.67 \mathrm{~b}$ & $64.34 \mathrm{~b}$ \\
\hline Shatabdi & $0.35 \mathrm{a}$ & $2.18 \mathrm{a}$ & $75.09 \mathrm{a}$ & $41.26 \mathrm{a}$ & $78.33 \mathrm{a}$ \\
Gourab & $0.31 \mathrm{~b}$ & $2.1 \mathrm{a}$ & $67.12 \mathrm{~b}$ & $38.70 \mathrm{~d}$ & $65.65 \mathrm{~h}$ \\
Protiva & $0.29 \mathrm{~b}$ & $2.03 \mathrm{~b}$ & $63.38 \mathrm{c}$ & $39.67 \mathrm{c}$ & $62.37 \mathrm{c}$ \\
Kanchan & $0.29 \mathrm{~b}$ & $2.0 \mathrm{c}$ & $63.09 \mathrm{c}$ & $39.69 \mathrm{~b}$ & $62.12 \mathrm{c}$ \\
\hline $\mathrm{N}_{0 \%}$ & $0.23 \mathrm{~d}$ & $1.95 \mathrm{~d}$ & $28.12 \mathrm{~d}$ & $42.09 \mathrm{a}$ & - \\
$\mathrm{N}_{50 \%}$ & $0.25 \mathrm{c}$ & $2.00 \mathrm{c}$ & $56.31 \mathrm{c}$ & $41.45 \mathrm{~b}$ & I 12.0a \\
$\mathrm{N}_{100 \%}$ & $0.35 \mathrm{~b}$ & $2.13 \mathrm{~b}$ & $83.62 \mathrm{~b}$ & $38.54 \mathrm{c}$ & $83.62 \mathrm{~b}$ \\
$\mathrm{~N}_{150 \%}$ & $0.42 \mathrm{a}$ & $2.23 \mathrm{a}$ & $100.7 \mathrm{a}$ & $37.23 \mathrm{~d}$ & $71.26 \mathrm{c}$ \\
\hline $\mathrm{CV}(\%)$ & 0.33 & 4.94 & 0.39 & 0.11 & 0.32 \\
\hline
\end{tabular}

\section{Nitrogen use efficiency}

The highest nitrogen use efficiency (physiological) (63.38 kg grain/kg N uptake) was observed in bed planting system followed by conventional system (50.85 kg grain/kg $\mathrm{N}$ uptake). Among the varieties, Shatabdi showed maximum $\mathrm{N}$ use efficiency (41.26 kg grain/kg $\mathrm{N}$ uptake) (Table 1). At zero $\mathrm{N}$ treatment, the maximum $\mathrm{N}$ use efficiency was found (42.09 $\mathrm{kg}$ grain/ $\mathrm{kg} \mathrm{N}$ uptake) followed by $50 \% \mathrm{~N}, 100 \% \mathrm{~N}$ and $150 \% \mathrm{~N}$ application (Table 1). Interaction of crop varieties and method of sowing, Shatabdi showed the highest (42.74 kg grain/kg N uptake) nitrogen use efficiency in bed planting system followed by Gourab (Table 2). Combined effect of sowing method and nitrogen level had significant effect on nitrogen use efficiency. The highest nitrogen use efficiency (43.24 kg grain/kg N uptake) was found at zero $\mathrm{N}$ treatment in conventional planting system compared to rest of the $\mathrm{N}$ levels applied. The lowest nitrogen use efficiency (36.55 kg grain/kg $\mathrm{N}$ uptake) was found at $1500 \%) \mathrm{N}$ treatment in bed planting system (Table 3). Thakur et al. (1998), Tripathi et al. (2004) and Alom et al. (2005) reported similar results in wheat. 
Table 2. Effect of sowing method and variety on $\mathrm{N}$ content (\%), $\mathrm{N}$ use efficiency and fertilizer recovery percentage (Pooled over two years).

\begin{tabular}{l|l|l|l|l|l}
\hline $\begin{array}{l}\text { Sowing method X } \\
\text { Variety }\end{array}$ & $\begin{array}{c}\text { Nitrogen } \\
\text { content of } \\
\text { straw (\%) }\end{array}$ & $\begin{array}{c}\text { Nitrogen } \\
\text { content of } \\
\text { grain (\%) }\end{array}$ & $\begin{array}{c}\text { Total } \\
\text { N uptake } \\
(\mathrm{kg} / \mathrm{ha})\end{array}$ & $\begin{array}{c}\text { N use } \\
\text { efficiency (kg } \\
\text { grain/ha per kg } \\
\text { uptake of N) }\end{array}$ & $\begin{array}{c}\text { Fertilizer } \\
\text { recovery } \\
\text { percentage }\end{array}$ \\
\hline $\begin{array}{l}\text { Raised bed } \\
\text { Shatabdi }\end{array}$ & $0.40 \mathrm{a}$ & $2.23 \mathrm{a}$ & $79.62 \mathrm{a}$ & $42.74 \mathrm{a}$ & $78.08 \mathrm{a}$ \\
Gourab & $0.31 \mathrm{~b}$ & $2.16 \mathrm{~b}$ & $71.05 \mathrm{~b}$ & $37.21 \mathrm{~b}$ & $69.86 \mathrm{~b}$ \\
Protiva & $0.31 \mathrm{~b}$ & $2.1 \mathrm{c}$ & $66.89 \mathrm{c}$ & $39.79 \mathrm{e}$ & $66.0 \mathrm{c}$ \\
Kanchan & $0.30 \mathrm{c}$ & $2.1 \mathrm{c}$ & $66.72 \mathrm{c}$ & $38.93 \mathrm{f}$ & $651.2 \mathrm{c}$ \\
\hline Conventional bed & & & & \\
Shatabdi & $0.31 \mathrm{~b}$ & $2.09 \mathrm{a}$ & $70.56 \mathrm{~b}$ & $40.56 \mathrm{~b}$ & $78.58 \mathrm{a}$ \\
Gourab & $0.29 \mathrm{~b}$ & $2.08 \mathrm{a}$ & $63.23 \mathrm{~d}$ & $40.19 \mathrm{~d}$ & $61.45 \mathrm{~d}$ \\
Protiva & $0.28 \mathrm{~d}$ & $1.94 \mathrm{c}$ & $59.87 \mathrm{e}$ & $38.77 \mathrm{~g}$ & $58.73 \mathrm{e}$ \\
Kanchan & $0.28 \mathrm{~d}$ & $2.04 \mathrm{~b}$ & $59.47 \mathrm{e}$ & $40.46 \mathrm{c}$ & $58.63 \mathrm{e}$ \\
\hline CV(\%) & 0.33 & 4.94 & 0.39 & 0.11 & 0.32 \\
\hline
\end{tabular}

Columns having the dissimilar letter/letters indicate significant differences at 0.05 levels of significance (Duncan's test).

\section{Fertilizer recovery percentage}

Maximum fertilizer recovery percentage (69.89\%) was obtained from bed planting system due to more uptake of N. Among the crop varieties, Shatabdi noticed highest fertilizer recovery percentages (78.33\%) might be due to high response to $\mathrm{N}$ fertilizer followed by Gourab. Due to $\mathrm{N}$ levels, the highest fertilizer recovery percentage (112.0\%) was found at $50 \% \mathrm{~N}$ application followed by $100 \% \mathrm{~N}$ and $150 \% \mathrm{~N}$ applications due to more leaching and volatilization loss for increasing rate of $\mathrm{N}$ doses (Table 1 ). The lowest fertilizer recovery percentage (71.26\%) was found at $150 \% \mathrm{~N}$ application (Table 1). Combined effect of sowing method and crop varieties had significant effect on fertilizer recovery percentages. The highest fertilizer recovery percentage was found in Shatabdi (78.08\%) in bed planting system, which was identical with conventionally planting Shatabdi. The lowest fertilizer recovery percentage was found in Protiva and Kanchan in conventional planting system (Table 2). Interaction effect of sowing method and nitrogen level had also significant effect on fertilizer recovery percentage due to nitrogen doses. The highest fertilizer recovery percentage (120.03\%) was found at 50\% N application followed by $100 \% \mathrm{~N}$ and $150 \% \mathrm{~N}$ applications in bed planting system (Table 3). The lowest fertilizer recovery percentage was obtained at $150 \% \mathrm{~N}$ application in bed planting system. 
Table 3. Effect of $\mathbf{N}$ and sowing method on $\mathbf{N}$ content, $\mathbf{N}$ use efficiency and fertilizer

\begin{tabular}{l|l|l|l|l|l}
\multicolumn{6}{c}{ recovery percentage (Pooled over two years). } \\
\hline $\begin{array}{c}\text { Sowing method X } \\
\text { Nitrogen level }\end{array}$ & $\begin{array}{c}\text { Nitrogen } \\
\text { content of } \\
\text { straw (\%) }\end{array}$ & $\begin{array}{c}\text { Nitrogen } \\
\text { content of } \\
\text { grain (\%) }\end{array}$ & $\begin{array}{c}\text { Total } \\
\text { N uptake } \\
(\mathrm{kg} / \mathrm{ha})\end{array}$ & $\begin{array}{c}\mathrm{N} \text { use } \\
\text { efficiency (kg } \\
\text { grain/ha per kg } \\
\text { uptake of N) }\end{array}$ & $\begin{array}{c}\text { Fertilizer } \\
\text { recovery } \\
\text { percentage }\end{array}$ \\
\hline Raised bed & & & & \\
$\mathrm{N}_{0 \%}$ & $0.24 \mathrm{f}$ & $2.06 \mathrm{abc}$ & $30.32 \mathrm{dg}$ & $40.95 \mathrm{c}$ & - \\
$\mathrm{N}_{50 \%}$ & $0.27 \mathrm{e}$ & $2.03 \mathrm{bcd}$ & $60.02 \mathrm{e}$ & $40.08 \mathrm{~d}$ & $120.0 \mathrm{a}$ \\
$\mathrm{N}_{100 \%}$ & $0.37 \mathrm{c}$ & $2.17 \mathrm{ab}$ & $67.85 \mathrm{c}$ & $37.1 \mathrm{gg}$ & $87.85 \mathrm{c}$ \\
$\mathrm{N}_{150 \%}$ & $0.48 \mathrm{a}$ & $2.25 \mathrm{ab}$ & $106.04 \mathrm{a}$ & $36.55 \mathrm{~h}$ & $70.69 \mathrm{f}$ \\
\hline Conventional bed & & & & & \\
$\mathrm{N}_{0 \%}$ & $0.21 \mathrm{~h}$ & $1.88 \mathrm{~d}$ & $25.90 \mathrm{~h}$ & $43.24 \mathrm{a}$ & - \\
$\mathrm{N}_{50 \%}$ & $0.23 \mathrm{~g}$ & $1.95 \mathrm{~cd}$ & $52.59 \mathrm{f}$ & $42.82 \mathrm{~b}$ & $105.18 \mathrm{~b}$ \\
$\mathrm{~N}_{100 \%}$ & $0.33 \mathrm{~d}$ & $2.09 \mathrm{ab}$ & $79.38 \mathrm{~d}$ & $39.98 \mathrm{e}$ & $79.38 \mathrm{~d}$ \\
$\mathrm{~N}_{150 \%}$ & $0.38 \mathrm{~b}$ & $2.23 \mathrm{a}$ & $95.26 \mathrm{~b}$ & $37.91 \mathrm{f}$ & $71.8 \mathrm{le}$ \\
\hline $\mathrm{CV}(\%)$ & 0.33 & 4.94 & 0.39 & 0.11 & 0.32 \\
\hline
\end{tabular}

\section{Yield and yield components}

\section{Effect of sowing method}

Higher number of tillers (2.51) was obtained in bed planting system as compared to conventional planting system (2.46 no.) (Table 4). Longer period (106 days) was required for physiological maturity at bed planting system compared to conventional planting system (101 days). More spikes $\left(234 \mathrm{no} . / \mathrm{m}^{2}\right)$ were found in bed planting system and minimum $\left(210 / \mathrm{m}^{2}\right)$ in conventional planting system. Highest number of spikelets per spike (17.27) was produced from bed planting system and lower from conventional planting system (16.77). The weight of 1000-grain (41g) was higher in raised bed compared to conventional planting system (40g). Higher grain yield (2,555 kg/ha) was recorded from bed planting system due to the maximum tillers, highest number of grains per spike and higher 1000 -grain weight and lower grain yield (2359 kg/ha) was found in conventional planting (Table 4).

\section{Effect of variety}

Among the varieties, the highest number of tillers per plant was obtained in Shatabdi (2.53) followed by Protiva (2.41) (Table 4). Shatabdi required maximum period (107) for physiological maturity and Gourab required minimum number of days. Shatabdi produced maximum number of spikes $\left(249 \mathrm{~m}^{2}\right)$ and minimum in Protiva. The highest spikelets per spike was observed in Shatabdi (19.47) and lowest in Gourab (16.79). Maximum number of grains per spike was 
observed in Shatabdi (45) followed by Gourab. Shatabdi produced the highest 1000-grain weight (42g) among the varieties studied. Shatabdi produced significantly the highest grain yield $(2,929 \mathrm{~kg} / \mathrm{ha})$. This was due to the maximum expression of important yield attributes like number of litters per plant, spikelets per spike, grains per spike and 1000-grain weight in bed planting system followed by conventional p1aiting system and lowest grain yield (2,445 kg/ha) was obtained in conventional planting system with Kanchan (Table 4).

Table 4. Effect of sowing method, variety and $\mathrm{N}$ level on yield and yield components (Pooled over two years) of wheat.

\begin{tabular}{|c|c|c|c|c|c|c|c|}
\hline Sowing method & $\begin{array}{l}\text { Tillers/ } \\
\text { plant }\end{array}$ & $\begin{array}{l}\text { Days to } \\
\text { maturity }\end{array}$ & Spike/m² & $\begin{array}{l}\text { Spike- } \\
\text { lets/ } \\
\text { spike }\end{array}$ & $\begin{array}{l}\text { Grains/ } \\
\text { spike }\end{array}$ & $\begin{array}{c}\text { 1000-grain } \\
\text { wt (g) }\end{array}$ & $\begin{array}{c}\text { Yield } \\
(\mathrm{kg} / \mathrm{ha})\end{array}$ \\
\hline Bed planting & $2.51 \mathrm{a}$ & 106a & $234 a$ & $17.27 \mathrm{a}$ & $42 a$ & $41.00 \mathrm{a}$ & 2555 a \\
\hline $\begin{array}{l}\text { Conventional } \\
\text { planting }\end{array}$ & $2.46 \mathrm{~b}$ & 101b & $210 b$ & $16.77 \mathrm{~b}$ & $39 b$ & $40.00 \mathrm{~b}$ & 2359b \\
\hline \multicolumn{8}{|l|}{ Variety } \\
\hline Shatabdi & $2.53 \mathrm{a}$ & $107 a$ & $249 a$ & $19.37 a$ & $45 a$ & $42.46 a$ & 2929a \\
\hline Gourab & $2.37 \mathrm{bc}$ & 101c & $239 b$ & $16.79 \mathrm{c}$ & $44 \mathrm{~b}$ & $40.83 b$ & $2559 b$ \\
\hline Protiva & $2.41 \mathrm{~b}$ & $103 b$ & $225 c$ & $18.91 b$ & $43 b c$ & $37.50 c$ & 2530c \\
\hline Kanchan & $2.19 \mathrm{c}$ & $104 \mathrm{~b}$ & $237 b$ & $18.16 \mathrm{~b}$ & $42 c$ & 38.92bc & $2445 d$ \\
\hline \multicolumn{8}{|l|}{ Nitrogen level } \\
\hline $\mathrm{N}_{0 \%}$ & $1.32 \mathrm{c}$ & $98 d$ & 153d & $14.29 \mathrm{c}$ & $32 d$ & $38.00 \mathrm{c}$ & l177d \\
\hline $\mathrm{N}_{50 \%}$ & $2.05 b$ & $102 c$ & 205 c & $1.46 \mathrm{be}$ & $40 c$ & $39.00 \mathrm{c}$ & $2326 c$ \\
\hline $\mathrm{N}_{100 \%}$ & $2.47 \mathrm{~b}$ & $105 b$ & $279 b$ & 16.88ab & $44 \mathrm{~b}$ & $41.00 \mathrm{~b}$ & $32 \mathrm{l5b}$ \\
\hline $\mathrm{N}_{150 \%}$ & $3.16 \mathrm{a}$ & $107 a$ & $313 a$ & 18.2lab & $47 a$ & $44.00 \mathrm{a}$ & $3746 a$ \\
\hline CV(\%) & 9.76 & 0.31 & 0.95 & 1.85 & 3.30 & 2.25 & 0.46 \\
\hline
\end{tabular}

Columns having the dissimilar letter/letters indicate significant differences at 0.05 levels of significance (Duncan's test).

\section{Effect of nitrogen level}

Highest numbers of tillers were found at $150 \% \mathrm{~N}$ (3.16 no.) being followed by $100 \% \mathrm{~N}$ and $50 \% \mathrm{~N}$. Maximum number of days (107 days) were required when $150 \% \mathrm{~N}$ was applied for physiological maturity followed by $100 \% \mathrm{~N}$ and $50 \% \mathrm{~N}$ (Table 4). Maximum number of spikes per $\mathrm{m}^{2}$ (313 no.) was obtained when $150 \%$ $\mathrm{N}$ was applied compared to remaining doses of $\mathrm{N}$ and minimum in stress nitrogen treatments. Spikelets per spike differed significantly among the $\mathrm{N}$ treatments and highest value was observed at $150 \% \mathrm{~N}$ (1821 no.) and lowest at $\mathrm{N}$ stress treatment (1429). Maximum number of grains per spike was observed at $150 \% \mathrm{~N}$ (47 no.) and lowest at $\mathrm{N}$ stress condition. At 150\% N treatment, highest 1000grain weight (44.00) was obtained among the treatments combinations. The highest grain yield of $3,746 \mathrm{~kg} /$ ha was recorded under highest level of $\mathrm{N}$ application $(150 \% \mathrm{~N})$ due to the highest $\mathrm{N}$ response to the crops and its use 
efficiency resulting significantly the maximum tillers, highest 1000-grain weight (44g) and higher number of grains per panicle (47). The lowest grain yield was obtained $(1,443 \mathrm{~kg} / \mathrm{ha})$ from the stress nitrogen treatment due to poor tiller number per plant, lowest 1000-grain weight and minimum number of grains per spike. Maximum days were required for physiological maturity at $150 \mathrm{~kg} \mathrm{~N}$ compared to $100 \% \mathrm{~N}$ and $50 \% \mathrm{~N}$ (Table 4).

\section{Interaction effect of variety and sowing method}

The interaction effects of sowing method and wheat varieties on yield and most yield contributing components were significant (Table 5). Highest number of tillers per plant was obtained from Shatabdi (2.93 no.) in bed planting system followed by conventional planting. Shatabdi required maximum number of days (107 days) in bed planting system for physiological maturity followed by conventional planting. Shatabdi produced maximum number of spikes $\left(228 / \mathrm{m}^{2}\right)$ in bed planting system than remaining varieties and minimum was in Kanchan with conventional planting. Spikelets per spike differed significantly among the varieties and the highest was observed in Shatabdi (20.10) and lowest in Gourab (16.15). Maximum number of grains per spike was observed in Shatabdi (45 no.) in bed planting system followed by (41 no.). Shatabdi produced highest 1000grain weight (44g) among the varieties. Shatabdi produced significantly the highest grain yield (2,918 kg/ha) in bed planting system. This might be due to the maximum expression of important yield attributes (maximum number of tillers, spikelets/spike, grains/spike, and 1000-grain weight) followed by conventional methods of sowing and lowest grain yield (2,205 kg/ha) was obtained in conventional planting system with Kanchan (Table 5).

Table 5. Effect of sowing method and variety on yield and yield components (Pooled over two years) of wheat.

\begin{tabular}{|c|c|c|c|c|c|c|c|}
\hline $\begin{array}{c}\text { Sowing method } \\
\text { X Variety }\end{array}$ & $\begin{array}{l}\text { Tillers/ } \\
\text { plant }\end{array}$ & $\begin{array}{l}\text { Days to } \\
\text { maturity }\end{array}$ & Spikes $/ \mathrm{m}^{2}$ & $\begin{array}{l}\text { Spike- } \\
\text { lets/ } \\
\text { spike }\end{array}$ & $\begin{array}{l}\text { Grains/ } \\
\text { spike }\end{array}$ & $\begin{array}{c}\text { 1000-grain } \\
\text { wt (g) }\end{array}$ & $\begin{array}{c}\text { Yield } \\
\text { (kg/ha) }\end{array}$ \\
\hline \multicolumn{8}{|l|}{ Bed planting } \\
\hline Shatabdi & 2.93 & $107 a$ & $228 \mathrm{a}$ & $20.10 a$ & $45.00 \mathrm{a}$ & $44.34 \mathrm{a}$ & 2918a \\
\hline Gourab & 2.64 & $105 c$ & $213 b$ & $16.15 c$ & $41.00 \mathrm{c}$ & $42.45 b c$ & $2575 c$ \\
\hline Protiva & 2.32 & $106 b$ & $204 b c$ & $17.03 \mathrm{bc}$ & $42.00 \mathrm{bc}$ & $39.43 e$ & 2390d \\
\hline Kanchan & 2.30 & $106 b$ & $208 b c$ & $18.04 b$ & $42.00 \mathrm{bc}$ & 40.1Scd & 2338d \\
\hline \multicolumn{8}{|c|}{ Conventional planting } \\
\hline Shatabdi & 2.65 & $106 b$ & $213 b$ & 17.10bc & $44.00 \mathrm{~b}$ & 42.37ab & $2660 b$ \\
\hline Gourab & 2.36 & $105 c$ & 198cd & $17.15 b c$ & $42.00 \mathrm{bc}$ & $41.38 \mathrm{bc}$ & 2353d \\
\hline Protiva & 2.07 & $105 c$ & 198cd & $17.05 \mathrm{bc}$ & $42.00 \mathrm{bc}$ & 39.85e & 2219e \\
\hline Kanchan & 2.03 & $106 b$ & $196 \mathrm{~d}$ & $17.07 \mathrm{bc}$ & $42.00 \mathrm{bc}$ & 40.34de & $2205 e$ \\
\hline $\mathrm{CV}(\%)$ & 2.41 & 1.15 & 10.10 & 1.85 & 3.30 & 2.25 & 1.26 \\
\hline
\end{tabular}




\section{Interaction effect of sowing method and $\mathrm{N}$ level}

Highest numbers of tillers per plant was produced at 150\% N (3.30 no.) in bed planting system followed by $100 \% \mathrm{~N}$ and $50 \% \mathrm{~N}$. Maximum number of days were required when $150 \% \mathrm{~N}$ was applied (109 days) for physiological maturity in bed planting system followed by $100 \% \mathrm{~N}$ and $50 \% \mathrm{~N}$. Maximum number of spikes $\left(258 / \mathrm{m}^{2}\right)$ was produced when $150 \% \mathrm{~N}$ was applied compared to remaining doses of $\mathrm{N}$ and minimum in stress nitrogen in conventional planting. The highest spikelets per spike was observed at 150\% N (19.54) and lowest (5.83) at nitrogen stress condition. Maximum number of grains per spike (46) was observed at $150 \% \mathrm{~N}$ and the lowest at nitrogen stress condition. At $150 \% \mathrm{~N}$ treatment, highest 1000-grain weight (44.18) was obtained among the treatments combination. The highest grain yield $(3,323 \mathrm{~kg} / \mathrm{ha}$ was obtained at $150 \% \mathrm{~N}$ application might be due to the maximum spikes per $\mathrm{m}^{2}$, highest 1000 -grain weight, and maximum number of tillers per plant followed by conventional planting system The lowest grain yield $(1,418 \mathrm{~kg} / \mathrm{ha})$ was obtained at zero nitrogen treatment with conventional planting system (Table 6). These results are similar with the findings of many other authors (Tripathi et al., 2004; Hossain et al 2004, and Sakartono et al., 2004).

Table 6. Effect of sowing method and $\mathrm{N}$ Level on yield and yield components.

\begin{tabular}{l|lll|l|l|l|l|l}
\hline $\begin{array}{c}\text { Sowing method } \\
\text { X level }\end{array}$ & $\begin{array}{c}\text { Tillers/ } \\
\text { plant }\end{array}$ & $\begin{array}{c}\text { Days to } \\
\text { maturity }\end{array}$ & Spike/m² & $\begin{array}{c}\text { Spike- } \\
\text { lets/spike }\end{array}$ & $\begin{array}{c}\text { Grains/ } \\
\text { Spike }\end{array}$ & $\begin{array}{c}\text { 1000-grain } \\
\text { wt (g) }\end{array}$ & $\begin{array}{c}\text { Yield } \\
\text { (kg/ha) }\end{array}$ \\
\hline Bed planting \\
$\mathrm{N}_{0 \%}$
\end{tabular}

Columns having the dissimilar letter/ letters indicate significant differences at 0.05 levels of significance (Duncan's test).

\section{Conclution}

It is revealed from the study that maximum yield potential of wheat can be achieved from the soil of Wheat Research Center, Rajshahi by growing the variety Shatabdi in raised bed ( $15 \mathrm{~cm}$ above the soil surface) and applying $\mathrm{N}$ at $150 \% \mathrm{~N}$ of the recommended doses.

\section{References}

Alam M. Z., S. A. Haider and N. K. Paul. 2004. Study of diversity estimates of yield and yield related characters in response to nitrogen fertilizer of barley genotypes (Hordeum vulgare L.). Bangladesh J. Genet. Biotechnol. 5 (1\&2): 19-21. 
AOAC. 1980. Official Methods of Analysis. Association of Official Analysis Chemists. 13 Ed. Washington DC. 2004. p. 220. Irrigation, plant type and nitrogen. Australian J. Expi. Agril. 38: 261-271.

Bell, M. A. and R. A. Fischer. 1994. Guide to plant and crop sampling: Measurements and observations for agronomic and physiological research in small grain cereals. Wheat special report no. 32. CIMMYT, Mexico, D.F. pp. 1-30.

Ciobanu, G., C. Hera, F. Zapata and H. Aman. 1995. Possibilities of increasing N use efficiency in winter and spring wheat. Analele Institutului de Cercetari Pentrucereal Si Plante Tehnice, Fundulea. 62: pp.121-137.

Fischer, R. A. 1981. Development in wheat agronomy. In: L. T. Evans and Peacock, W. I. eds.Wheat Science Today and Tomorrow, Ed. Cambridge. University Press, Cambridge. pp. 249-270.

Fertilizer Recommendation Guide. 2005. Bangldesh Agricultural Research Council (BARC), 2005. pp: 200-204.

Gomez, K. A. and A. A. Gomez. 1984. Statistical Procedure for Agricultural Research. $2^{\text {nd }}$ Ed. John Wiley and Sons. New York, Chichester, Brisbane, Toronto, Singapore. p.680.

Hossain, M. I., C. A. Meisner, G. A, Kabir, F. M. Alam, J. M. Duxbury, J. G. Lauren, M. M. Rah man, M. M. Meer and R. H. Rashi. 2004. Use of raised beds for increasin wheat production in rice-wheat-cropping system. In: Handbook and Abstract, $4^{\text {th }}$ International Crop Science Congress, Brisbane, Australia. p.120.

Kumar, A., D. K. Sharma and H. C. Sharma. 1995. Nitrogen uptake, recovery and N use efficiency in wheat (Triticum aestivum) as influenced by nitrogen and irrigation levels in semi- reclaimed sodic soils. Indian J. Agron. 40 (2): pp.198-203.

Meisner, C. A., E. Acevedo, B. Flores, K. D. Sayre, M. I. Ortiz and D. Byerlee. 1992. Wheat production and grower's practices in the Yaqui Valley. Wheat special report 6, Mexico. p. 75.

Sayre, K. D. 1998. Use of raised bed-planting systems to different field crops. Key note paper, presented at the training course on "Bed and zero tillage system" held on 18 May to 30 July 2004. CIMMYT, Mexico, D.F. pp. 1-13.

Sukartono, S. Jaikiraty, Gill, M. Ma’Shum, I. G. M. Kusnarrta, Mahrup, B. McKenzie and J. Tiosdall. 2004. Raised beds improve secondary crop production in the rainfed rice-based cropping systems of Southern Intlonesia. In: Handbook and Abstract, $4^{\text {th }}$ International Crop Science Congress, Brisbane, Australia. p.1 38.

Thakur, S. S., I. B. Pandey, S. J. Singh and S. S. Mishra. 1998. Nitrogen uptake and productivity of late sown wheat (Triticum aestivum) as influenced by row spacing and weed management. Indian J. Agron. 43 (3): pp. 5 18-523.

Tripathi, S. C., K.D. Sayre and J. N. Kaul. 2004a. Genotypic effects on yield, N uptake, NUE and NHI of spring wheat. In: Handbook and Abstract, 4th International Crop Science Congress Brisbane, Australia. p. 182. 